\title{
The role of parents in the development of faith from birth to seven years of age
}

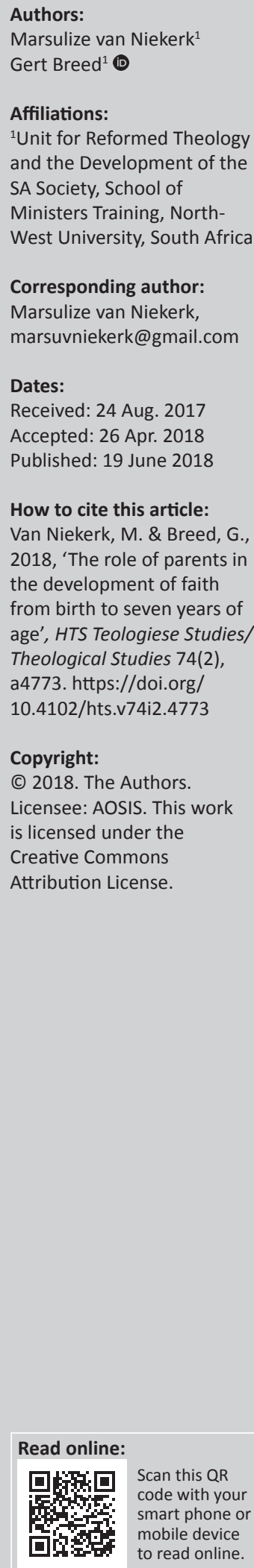

Scholars have researched the role of parents in the development of the child. Families play a critical role in the development of a young child. According to Freud, many adult symptoms of anxieties are rooted in childhood experiences, and that a child's development would influence how the child would behave as an adult and that their actions may correlate to something that occurred in their childhood. Erikson's theory of ego development stated that the ego, which is the centre of each person's individuality, could not be understood in isolation from the others and the wider world around it. Research has also been done on the way that a person's faith develops. In his book, Stages of Faith, Fowler developed a theory of six stages that people go through as their faith matures. Keeley, combined his knowledge of education with his passion for children's ministry and published a book with the title, Helping Our Children Grow In Faith. As a theology student with a background in Early childhood development, the researcher believes that these two academic areas should be utilised together to assist parents in the process of the child's faith development during its formative years. Osmer's core task of Practical Theology, and its four questions, will be used to determine parents' roles in the faith development of their children. Empirical data gathered in a study by Nel and Van der Westhuizen will be used. When all four questions are answered, this study will deduce useful guidelines for parents. The importance of the role that parents play in the faith development of children is immense. A baby's or an infant's interaction with his or her parents forms the basis on which he or she will build their developing faith. If this foundation is not placed down correctly, problems might arise later in the child's faith development.

\section{Introduction}

A study conducted by Nel and Van der Westhuizen (2015:14) indicates that parents play an important role in the faith development of their children. This article will focus on this role that parents play and attempt to determine, using Osmer's (2008:4) core task of practical theology and its four questions, the role that parents play, why they play this role and how parents can be guided through Deuteronomy 6:4-9 in this faith development journey of their children and give further practical guidelines. Osmer's (2008:4) core task is used as it seeks to bring theory in line with the practical, and this study is conducted to align the theory gathered with how it can be used in a practical manner:

Faith development theory and research have focused on a generic understanding of faith that sees it as foundational to social relations, to personal identity, and to the making of personal and cultural meanings. (Fowler \& Dell 2006:36)

To be able to discuss the faith development of a child, one must first ask what faith development is? Many scholars have formulated definitions on how faith development can be categorised (see Dettoni 1994:11; Matthaei 2000:22; Prins 1995:24). When these ideas are combined, one could come to the following statement: Faith development is an intentional process by which the faithful are guided to grow in their relationship with God and the accompanying change in lifestyle. It involves the development of the believer's identity and calling in Christ (Avenant 2015:63). Faith development is participating in God's work of grace in the believer's life and this is a lifelong process (Avenant 2015:65). Fowler (1991:31) defines faith as 'universal quality of human meaning making'. According to Fowler (1987:32-33), the way we hold our faith can pass through up to seven stages (stage 0 to stage 6). At each stage, we 'faith' differently. When we move from one stage to the next, we suffer the trauma of losing one familiar way of being in faith before we can take up the next style of faith. As we develop, the faith contents from each earlier stage are carried over and reworked by the different structures of thinking and relating of the new stage of our faith. 
Faith development is the process of growing and changing physically, cognitively, spiritually and emotionally in the understanding of our faith, which can be defined as your relationship with God, and the people who have an impact or influence on this relationship, for example, family, friends, people who attend the same congregation, reverent or catechesis teacher. Martin Luther outlines the 'who' that are responsible for the fostering, inspiring, directing and teaching in this process of faith development, when he calls upon a partnership between government officials, pastors and parents to take responsibility for the teaching and training of the children who form part of their faith communities (Arand 2000:94-95):

Of these three groups, Luther placed the greatest emphasis on the family. From the very beginning of the evangelical movements, parents were enlisted as valued allies in the formation of holy households. (p. 95)

Although there has been an increase in research on the faith development of children during the last two decades, Fowler provides individuals with a framework to identify where they find themselves, and those around them, in terms of faith development (Love 2002; Lownsdale 1997; Parker 2011) Although Fowler's theory is clearly influential to the study of faith, as with any other theory, it is associated with strengths as well as weaknesses. Because this article is aimed at equipping parents, who might not have the knowledge, in assisting their children with faith development, the basicness of Fowler's theory makes it ideal.

The argument that family structure plays no role is questioned by many research results (Van Staden 2015:14). Everything indicates that divorce, family conflict and the high occurrence of absentee fathers have a particularly negative impact on children, including an increased rate in emotional problems, depression, low self-esteem, learning difficulties and poor academic performance, absenteeism at school, suicide, isolation, behavioural problems, problems in romantic relationships, early pregnancy, divorce and aggression among boys (DeVries 2004:65; Gottman 2001:22; Holborn \& Eddy 2011:4). Family structures do not only have a social and psychological impact; Smith and Denton (2005:281) found that American teenagers whose biological or adoptive parents are married are more likely to demonstrate deep religious characteristics. It is for these reasons that Browning (2007:57) and Thatcher (1999:147) believe that the church must accept and support all families without reservation.

\section{What is going on: The role that parents currently play in the faith development of their children}

Osmer's (2008:4) first task of practical theology is the empirical-descriptive task that asks, 'What is going on?' To answer this question, information is gathered to help discern patterns in particular episodes and context. Here, the first question would be aimed at determining the role that parents currently play in the faith development of children.
TABLE 1: Person playing largest role in faith development as a child.

\begin{tabular}{lc}
\hline Largest role in faith development & Percentage \\
\hline Mother & 81 \\
Father & 66 \\
Reverend & 44 \\
Grandparents & 30 \\
Sibling & 17 \\
Other family member & 11 \\
\hline
\end{tabular}

Source: Nel, M. \& Van der Westhuizen, Z., 2015, Skokkend positief, Bybelmedia, Kaapstad

\section{The role parents play today}

In the past decades, various studies have indicated that families play an appreciable influence on the religiosity and religious involvement of young people (Benson \& Eklin 1990; DeVries 2004; Smith \& Denton 2005). South African churches have had to rely on studies conducted in other countries, and how comparable and applicable these results were to churches in South Africa was unsure (Van Staden 2015:13). In 2014, a research project, which consisted of respondents from the Nederduitsch Hervormde Kerk van Afrika, ${ }^{1}$ Gereformeerde Kerke in Suid-Afrika ${ }^{2}$ and Nederduitse Gereformeerde Kerk ${ }^{3}$, was started in South Africa with the title 'Church Youth and Religion in South Africa'.

Many of the respondents of this study, $65 \%$ of them, felt that families play an integral part of the Christian faith (Van Staden 2015:13). One of the questions enquired about which person played the largest role in the faith development of the respondents while they were young. The answers were as follows (see Table 1).

From these statistics, it becomes clear that both parents, but especially mothers, play a larger role in the faith development of children. Grandparents also seem to play a larger role in faith development, and siblings and other family members play a smaller role, but still form part of the people who play a role. The second part of the question asked respondents which person currently plays a role in their faith development. Where parents played the largest role when they were children and their reverends only came in third, with $44 \%$, the statistics for people who currently play a role in their faith development differs. Reverends now play the largest role, with $48 \%$. Mothers now play the second largest role, with $47 \%$, and fathers the third largest role with $38 \%$ (Van Staden 2015:14)

According to Van Staden (2015:15), the statistics for faith forming habits is lower than expected if the importance that parents play is taken into account. When asked about how regular the respondents would do Bible study with their parents, only $41 \%$ said that this would have happened on a regular basis, $65 \%$ of the respondents said that their parents had talked to them about religious issues, only $43 \%$ said that their parents spoke to them about their faith and only

1.Nederdutch Reformed Church of Africa.

2.Reformed Churches of South Africa.

3.Dutch Reformed Church. 
$19 \%$ said that their parents ever spoke to them about baptism. When asked about the people who had shared their 'faith stories', which was defined as 'to make a decision to accept Christ and my beliefs and to share Christian experiences', $58 \%$ of the respondents indicated that their mothers had shared these stories with them, $46 \%$ indicated that their father had shared the story with them, 30\% indicated that a sibling had shared his or her story with them, $27 \%$ indicated that another family member had shared their faith story with them and $26 \%$ indicated that one of their grandparents had told them their 'faith story' (Van Staden 2015:14). One of the questions asked of the respondents was how often they attend church with their families; $44 \%$ attend church with their families every week, $37 \%$ attend church two or three times a month, $16 \%$ attend church with their families only once a month and approximately $3 \%$ never attend church with their family. This means that at least $81 \%$ of the respondents attend church with their families two or more times a month (Van Staden 2015:15).

In the above-mentioned study, respondents were asked to answer questions about the faith forming habits that took place in their homes as well as the examples set by their parents regarding faith development. During these reflections, $95 \%$ of the respondents indicated that their values as Christians were influenced by the values that they saw modelled by their parents, and 91\% indicated that their choices are influenced by the values modelled to them by their parents (Avenant 2015:66). According to Avenant (2015:66), 11\% of the respondents indicated that no one and nothing in their homes played a role in the development of their faith. ${ }^{4}$

Although a high percentage of the respondents in this study attended church with their families on a regular basis, a much smaller number indicated that their parents spoke to them about their faith. According to Wuthnow (1999:11), a child's church attendance alone is not an indication of how that child would act later in life, but when combined with other religious customs and practices, can be used as an important barometer. According to Firet (1982:71-72) and Nel (2009:6), 'faith stories' play a crucial role in the initiation of children into the faith community. Boyatzis and Janickie (2003:263-265) also speak about the importance of this type of communication, and especially the importance of the role of mothers. Avenant (2015:44) therefore feels that the low number of parents who share these stories with their children is a problem. The question now arises whether parents do not realise the important effect that these stories would have on the faith development of their children, or if they do realise it and are just not equipped to share and talk to their children about this matter, and who should then assist parents in this.

When taking into account the important role that parents play, according to studies, in the faith development of young children, and the importance of regularly practicing faith and religion at home, the importance of parents in the faith development of children cannot be denied. Because of this, it is important to take into account faith development theories to better understand how this influence happens.

\section{Why is this going on: Factors that influence the role parents play in their children's faith development}

Osmer's second task of practical theology (2008:79) is the interpretative task. The task asks, 'Why is this going on?' Here, the second question would be aimed at interpreting faith development theories to determine why parents play this role.

In 1981, James W. Fowler ${ }^{5}$ published the findings of his study on the development of faith in people. Although everyone does not pass through all seven stages (Newberg 2012:39), it can still be used as a good guideline of how faith develops over the course of a human lifetime.

Westerhoff's (2000) ideas on faith development hint towards similar ideas as those of Fowler and will also be discussed.

\section{Fowler's stages of faith development}

For Fowler (1981:11), faith, as a universal human activity of meaning making, is grounded in certain structures, which are innate in human interactions that shape how human beings understand and interact with self and world. An important feature of Fowler's theory is that he separates the content of faith (e.g. beliefs and values) from psychological factors that facilitate the operation of faith within the personality (e.g. cognitive, affective and social development). In his view, the way in which people construe and relate to transcendent realities is determined by the receptivity and competence of psychological structures that underlie thinking, feeling and social processes (Jardine \& Viljoen 1992:75).

Fowler (1981:119-199) describes the following seven stages of faith development:

Stage 0: Primal or undifferentiated faith.

Stage 1: Intuitive-projective faith.

Stage 2: Mythic-literal faith.

Stage 3: Synthetic conventional faith.

Stage 4: Individuative-reflective faith.

Stage 5: Conjunctive faith.

Stage 6: Universalising faith.

When determining the role that parents play in the faith development of their children during the formative years,

5.James W. Fowler was a professor in Theology and Human Development at Emory University (1987-2005). 
the first two stages are of importance, as the children would pass through these stages from birth to seven years of age.

\section{Stage 0: Primal or undifferentiated faith}

James Fowler names this early, infancy state of being as 'primal faith'. During infancy, the time from birth to two years, faith development can be described as undifferentiated faith. This is a time before language, and conceptual thoughts are possible. The infant is forming a basic sense of trust and of being at home in the world. The infant is also forming what Fowler (1981:120) calls pre-images of God or the Holy, and of the kind of world he or she will live in. On this foundation of basic trust or mistrust is built all that comes later in terms of faith development. This stage occurs during the first preverbal year of life and, as basic trust or mistrust, is formed during these years. The child's faith development will later build on the trust or mistrust formed during this stage, by building on whether the child has built a healthy basis of trust or not (Parker 2011:113).

More physical and neurological growth and development occurs in the first year of life than during any other life stage (Fowler \& Dell 2006:36). In this first stage, a pre-language disposition of trust forms in the mutuality of one's relationships with parents and other caregivers, with a total emotional orientation of trust offsetting mistrust. It takes form in the mutuality of one's relationships with parents and others. It involves the basic rituals of care and interchange and mutuality (Fowler 1981:119). This sense of trust offsets the inevitable anxiety and mistrust that result from the succession of cognitive and emotional experiences of separation and self-differentiation, which occur during infant development. This stage is characterised by an early learning of the safety of their environment (warm, safe and secure vs. hurt, neglect and abuse). Experiences combining to form this trusting disposition include body contact and care; vocal and visual interplay; ritualised interactions associated with early play, feeding and tending; and the development of interpersonal affective atonement in the infant's relations with caregivers. Factors such as these activate pre-potentiated capacities for finding coherence and reliability in self and primal others, for forming bonds of attachment with them and for shaping a disposition to trust the larger value and meaning commitments conveyed in parental care. Attachment between the infant and her or his parent or caregiver is a process with important implications for the child's future relationships. Attachment refers to the emotional bond begun at birth and nurtured for months thereafter - that is enduring, specific to the individual adult and infant combination, and that both stimulates and is stimulated by physical closeness. After the first successful attachment to the primary caregiver, the infant can generalise the ability to attach emotionally to selected others. The first year is crucial in shaping the young child's ability to make healthy attachments in other relationships. For too many individuals, male and female, inadequate caregiving, abuse and neglect adversely affect this vital process. In Erikson's framework, the developmental task of this period is characterised as the development of a sense of basic trust (Erikson 1964; Zuckerman \& Frank \& Augustyn 1999). If consistent nurture is experienced, the child will develop a sense of trust and safety about the universe and the divine. On the contrary, negative experiences will cause the child to develop distrust with the universe and the divine.

Anxiety and mistrust have their own developmental pattern of emergence that caregivers' consistency and dependability help to offset (Erikson 1964; Fowler 1986b; 1996; Stern 1985). Transition to the next stage begins with integration of thought and languages which facilitates the use of symbols in speech and play.

This stage correlates with Piaget's sensorimotor stage. The sensorimotor stage is the first of the four stages in cognitive development which 'extends from birth to the acquisition of language' (Tuckman \& Monetti 2011:22). In this stage, infants progressively construct knowledge and understanding of the world by coordinating experiences, such as vision and hearing, with physical interactions with objects, such as grasping, sucking and stepping. Infants gain knowledge of the world from the physical actions they perform within it and they progress from reflexive, instinctual action at birth to the beginning of symbolic thought towards the end of the stage (Piaget 1964:176).

\section{Stage 1: Intuitive-projective faith}

The intuitive-projective stage characterises the child of two to six or seven. In young children, gross motor, fine motor and cognitive development are intertwined processes related to the maturation timetables of the central and peripheral nervous systems. Neurons are migrating, proliferating and making more complex connections (Fowler \& Dell 2006:37). Children become capable of more sophisticated communications with the production of neurotransmitters. Myelination, the sheathing of neurons in protective layers of fatty and protein substances, increases the rate of neuronal firing and facilitates faster, more complex signals between brain cells and from the brain to the rest of the body. The toddler and preschool periods are times of monumental brain development, continuing a young girl's or boy's susceptibility to physical and emotional neglect and abuse (Krug \& Mikus 1999:52). At this time, positive and negative images are formed. These images will play a role even long after formed and will later be sorted into self-reflective values and thoughts. During this stage, the child will become conscious of himself or herself for the first time, which makes him or her egocentric and unaware of the needs and opinions of other people (Fowler 1986b:227; Parker 2011:114).

During this stage, speech and symbols are used to organise sensory experience, and cause-effect relationships are poorly grasped. The child's logic is episodic and intuitive. Fantasy and reality interpenetrate, which leads to values that are shaped by stories. One of the strengths of this stage is the birth of imagination and its ability to unify experience through powerful images. Faith development may be limited 
by the fact that unrestrained or destructive images can terrorise the child (Parker 2011:114).

Cognitively, the toddler is in transition between Piagetian stages (Fowler \& Dell 2006:37). The last phase of the sensorimotor stage occurs in the first part of the 2 nd year. Piaget's preoperational stage emerges in the 3rd year as she tries out symbolic thought and representational play. Toddlers are curious about other children and progress from individual, solitary play to doing the same thing side by side, without significant interaction with each other (Fowler \& Dell 2006:37). For Erikson, the fundamental issue of this stage is autonomy versus shame and doubt, and, if all goes well, the desired outcomes are the positive qualities of self-control and willpower (Dell \& Dulcan 1998; Erikson 1964; Krug \& Mikus 1999; Piaget 1970). From the time children begin to use language to communicate about self and objects in the world, we see the emergence of a style of meaning making based on an emotional and perceptual ordering of experience. Imagination, not yet disciplined by consistent logical operations, responds to story, symbol, dream and experience (Fowler \& Dell 2006:37-38).

Children attempt to form images that can hold and order the mixture of feelings and impressions evoked by their encounters with the newness of both everyday reality and the penumbra of mystery that surrounds and pervades it. Death becomes a conscious focus as a source of danger and mystery. Experiences of power and powerlessness orient children to a frequently deep existential concern about questions of security, safety and the power of those on whom they rely for protection (Fowler \& Dell 2006:38). Fantasy and make-believe are not distinguished from factuality. Constructions of faith are drawn to symbols and images of visible power and size. Stories that represent the powers of good and evil in unambiguous fashion are prized; they make it possible for children to symbolise and acknowledge the threatening urges and impulses that both fascinate and disturb them, while providing an identification with the vicarious triumphs of good over evil that stories such as fairy tales can provide (Bettelheim 1991:36).

There is, in this stage, the possibility of aligning powerful religious symbols and images with deep feelings of terror and guilt, as well as of love and companionship. Such possibilities give this stage the potential for forming deep and long-lasting emotional and imaginal orientations - both for good and for ill (Fowler 1986a:16).

During this stage, children integrate and conceptualise God in the way that society has ingrained it into them through stories, fantasy and dramatic representations. The things that influence this conceptualisation of God would be plays or puppet shows of Bible stories, stories told during Christian holidays and simplistic prayers. These would be the acts that children draw their information about religious ideas from (Newberg 2012:41). At this age, a child's brain is constantly establishing many different connections and there is a tremendous expansion and overconnectedness between neurons (Newberg 2012:41-42) Because of this, there are few clearly defined rules and there is a sense of blending different experiences and ideas. Because of this, children will most likely not see the problem with blending ideas about God with mundane things (Newberg 2012:42). The following conclusions regarding faith development in children can be drawn from Fowler's faith development theory:

During the first 2 years of a child's life, he or she develops basic trust and empathy, or a lack thereof, with the one's providing care. The quality of interactions in this phase underlies all future faith development for the individual. When thought and language begin to open the child up to the use of symbols in speech and ritual play, the child moves on to Stage 1: Intuitive-projective faith, which is typical of children ages 2 through 7 . Here the child is egocentric. In this stage, the child's imagination is formed. But in this stage, reality is not well differentiated from fantasy. For this reason, adults preaching about the negative aspects of religion - the devil and the evils of sin - can cause great harm to a child of this age, leading him towards a very rigid, brittle and authoritarian personality as an adult. When a child attains the capacity for concrete operational thinking, he or she can begin to move towards the second of James Fowler's stages.

\section{Westerhoff's ideas on faith development}

Westerhoff (2000) wrote that:

there is a difference between learning about the Bible and living as a disciple of Jesus Christ. We are not saved by our knowledge, our beliefs, or our worship in the church; just as we are not saved by our actions or our religion. We are saved by the anguish and love of God, and to live according to that truth is to have faith. (p. ad loc)

He asks the question, 'Will our children have faith?', not 'will our children believe?', because 'faith' is more than the totality of our beliefs. According to Westerhoff (2000:ad loc), faith grows like the rings of a tree, with each ring adding to and changing the tree somewhat, yet building on that which has grown before. Therefore, Westerhoff (2000:ad loc) offers a tree analogy and proposes the following four rings which are involved in the growth process:

Experienced faith: This stage takes place during preschool and early childhood. During this stage, it is about: This is what 'we' do. This is how 'we' act. It is a time of imitation. For example, a child prays the Lord's Prayer without understanding the meaning of all the words.

Affiliative faith: This stage takes place during the late childhood and early adolescent years (age 10-14). During this stage, it is about: This is what 'we' believe and do. This is 'our' group/church. It is a time of belonging to a group but is also still a time which centres around the imitation of what the group does. 
Searching faith: This stage takes place during the late adolescence year (age 15-20). During this stage, it is about: Is this what ' $I$ ' believe? This is a time of asking questions and no longer blindly accepting what others have said. This stage of faith is adding the 'head' to the 'heart' of the earlier states.

Owned faith: This stage takes place during early adulthood (age 21-30). During this stage, it is about: This is what ' $I$ ' believe. This stage only comes through the searching stage. This is the strong, personal faith that one witnesses to and one is willing to die for (Westerhoff 2000:ad loc).

As this article only focuses on the role that parents play during a child's formative years (birth to age 7), only the 'Experienced faith' stage is of relevance.

\section{Experienced faith}

In the early years of life, we often state that faith is more 'caught' than 'taught.' Westerhoff (2000:ad loc) names this 'experienced faith'. This experienced faith occurs during a critical child developmental period of a person's life. Erik Eriksson and Jean Piaget, two major thinkers in child development, form the psychological foundation of Westerhoff's faith development theories (Zietlow 2007:3). It is critical during this infancy stage that a baby can develop a basic sense of trust in himself or herself, in other people and in the world in general. Infants need emotional support that includes attention, warmth and touch, interest in what they are doing and empathy. When these basic emotional needs are not met, a child is not able to sense the world as trustworthy, and the possibility of healthy future development, emotional, social, intellectual, and spiritual is compromised (Graven 1999:50-52). The failure to develop trust and to attach strongly to a caring adult has implications for the child's life of faith. A child who has not learnt to trust other people may find it difficult to trust God and God's care for him or her. The lack of empathy will limit the child's ability to love others as Jesus has loved us. The child's ability to trust and respond to those who have primary responsibility for their care is foundational for future development and critical in the way they hold their faith. Basic trust makes it possible for the child to have hope (Hymans 2004:36).

The key to experienced faith in early childhood is observation and reaction. Children observe love and faith in their interaction with adults and react to what they experience. At this stage, they are too young to consciously think about faith, but they demonstrate unwavering faith. The needs at this stage are to experience trust, love and acceptance. According to Westerhoff (2000:ad loc1976:98), little children need a few trusted and loving adults in their lives.

\section{The parent's role in faith development and these theories}

How do these theories relate to the question 'why parents play a role in the faith development of their children?'
According to Fowler (1981:119-121) and Westerhoff (2000:ad loc), the environment in which a child is raised and the relationships the child has with his or her caregivers play an important role in his or her faith development. This is reflected in an earlier study where $94 \%$ of the respondents indicated that they had positive relationships with their parents and 95\% felt that their parents accepted them for who they are (Avenant 2015:65-66).

Fowler (1981:123) indicates that imagination plays an important part in a child's faith development. The child's imagination can be best used through the telling of Bible stories that would broaden their knowledge of the Bible and assist in faith development; $96 \%$ of the respondents in this same study indicated that their parents took them to catechesis (Avenant 2015:67), where these stories form part of the curriculum. According to $66 \%$ of the respondents, attending catechesis played an important role in their faith development.

Westerhoff (2000:ad loc) states that children need to observe faith in their interaction with adults and be given the opportunity to react to what they experience. This is reflected in the fact that $81 \%$ of the respondents in the study attended church with their families regularly, $41 \%$ regularly did Bible study at home, $65 \%$ had discussions with their parents about religious matters such as baptism and $58 \%$ of their mothers and $47 \%$ of their fathers discussed their own faith story ${ }^{6}$ with them (Avenant 2015:65-67). According to Strommen (1973:28), children follow the examples set by their parents, whether good or bad. This is also reflected in the fact that $91 \%$ of the respondents indicated that their parent's morals and values had a direct influence on their own morals and values.

\section{Guidelines taken from ideas on faith development}

The following practical guidelines can be deducted from these ideas on faith development.

\section{Infancy (age 0-2)}

Although it seems implausible that any faith development could take place at this age, Fowler's work shows that it is important for children to have a healthy basis to build their faith on. Westerhoff's ideas on faith development (Westerhoff 2000:ad loc) hint to similar guidelines that can be followed by parents. He also states the importance of infants growing up in an environment that allows them to build trust in themselves as well as the other adults in their lives. Parents need to place emphasis on the development of trust between themselves and their child. The child's environment should be a safe one, and even though adults might see some of the child's needs as being mundane (feeding, sleeping, etc.), they still need to be fulfilled in order for the child to build the necessary trust.

6.Faith story can be defined as 'a decision to choose Christ and to share my Christian beliefs and experiences' (Avenant 2015:66). 


\section{Early childhood (age 3-7)}

Key words during this stage are imagination, visual, egocentric and example.

As the child's imagination plays a big role in their development (Fowler 1981:123), parents should make use of dramatic stories to teach a child more about God. Daniel in the Lions' Den, Samson and David and Goliath are all good examples of 'stories' that parents can tell their children that will allow them to build a basic knowledge of God. At this age, reality is not well differentiated from fantasy. For this reason, adults preaching about the negative aspects of religion - the devil and the evils of sin - can cause great harm to a child of this age.

Because the child can still be egocentric, parents should address their individual needs when it comes to their faith and its development. A simple scenario would be that instead of dealing with death, heaven and the afterlife in general, to wait until death has a personal impact on the child's life and then raising the subject with the child and explaining how it fits into his or her faith and religion.

During this stage, children acquire knowledge mainly through observation (Fowler 1981:124; 1986b:227; Parker 2011:114; Westerhoff 2000:ad loc). Parents should make use of this when talking to their children about faith. Something as simple as a picture in a children's Bible can be used to great effect. This includes the way they observe their parents dealing with faith and religion. The example set by these adults in a child's life is very important. An adult cannot teach a child that to tell a lie is a sin if the child observes the adult lying themselves.

Westerhoff (2000:ad loc) states that 'while we need to provide experiences for each style of faith, we also need to provide experiences that help persons to move from one style of faith to another'. As children during early childhood mainly receive these experiences from their parents, their parents should assist them in moving on to the next style of faith. Westerhoff (2000:ad loc) also states that another way the development of a child's faith can be understood is by looking at it in terms of human development and the maturation process from lower to higher stages of development. The child is seen as a seed and the parent as a gardener caring for the seed until they grow up naturally. 'This is the philosophy of Rousseau and the developmental psychology of Piaget' (Westerhoff 2000:ad loc).

\section{What should be going on: The parent's role and guidelines in the Bible}

Osmer's third task of practical theology (2008:79) is the normative task. The task asks, 'What ought to be going on?'. Here, the third question would be aimed at the exegesis of a biblical passage that will assist in understanding the role that parents should play in the faith development of their children.

\section{Deuteronomy 6:4-9 and faith development}

The fifth book of the Torah was known in Jewish circles as [הדברים אלה' [these are the words] (Harrison 1969:634). Deuteronomy consists of a collection of the last addresses given 'to all of Israel' by Moses, on the plains of Moab (Dt 1:1). Deuteronomy 6:4-97 forms part of a section which can be categorised as 'Exhortation of the Law' (Harrison 1969:634) or 'the shema' (Biddle 2003:143). ${ }^{8}$

It is important to note that this section (Dt 6:4-9) begins in Deuteronomy 5 where it is stated that Moses called 'כל־ישראל' [all of Israel]. The reason for this calling together of all Israel is to teach them the 'statutes and ordinances' of the Lord (Dt 5:1), so that they may organise their communal (including family) life according to the Lord's purposes (Biddle 2003:101). ${ }^{9}$ In Deuteronomy 6:7, the Israelites are ordered to teach their children about their faith diligently, as the future of the family and the nation depends on the religious education of the generations to come (Rushdoony 2008:117-118). Nakhai (2014:54) also highlights this importance of the pedagogical purpose of family religious education 'related to those aspects of life that were of greatest concern to all Israelites: sustenance and economic survival, on the one hand, and health and reproduction, on the other' (see also Christensen [2001:143] who focuses specifically on Deuteronomy). When using the term 'family' in the context of ancient Israel, it does not refer to a nuclear family as understood in the 21st century. Rather when Israel is told to think and talk of these teachings 'בביתך' [in your house], it is referring to the בית אב [father's house]. On the contrary, this בית אב so-called referred to the extended family in Israelite society who was, like all others ancient Mediterranean societies of this time, a collectivistic society (Pilch 2012:118).$^{10}$ This meant on the one hand that family centredness referred to the family as the centre of social interaction for the members thereof, but also on the other hand as the 'system of meaning' out of which the collective group organised their understanding of the world (McVann 1993:75-76; see also Faust \& Bunimovitz 2014; Nakhai 2014). This meant that each individual in the בית אב is:

dependent on others for their sense of identity, for their understanding of their role and status in society, for clues to the duties and rights they have, and for indications of what is honorable and shameful behavior. (Neyrey 1993:94; see also Pilch 2012:119-120)

7.4 ' Hear 0 Israel. The LORD our God, the LORD is one 5 You shall love the LORD your God with allyour heart and with all your soul and with all your might. 6 And your God with all your heart and with all your soul and with all your might. 6 And these words that I command you today shall be on your heart. 7 You shall teach them diligently to your children, and shall talk of them when you sit in your house, and when you walk by the way, and when you lie down, and when you rise. 8 You shall bind them as a sign on your hand, and they shall be as frontlets between your eyes. 9 You shall write them on the doorposts of your house and on your gates' ( Dt 6-4:9).

8.The reference to this section (Dt 6:4-9) as the shema comes from the first Hebrew word used in Deuteronomy 6:4: "שראל שמע" [hear, O Israel].

9.Although the focus of this discussion is on the family life (which was included in communal live; see below) of Israel, it should be noted that kinship (family), politics, economics and religion where not separate institutions (Horsley 2009:1-16). Thus, economics and religion where not separate institutions (Horsley 2009:1-16). Thus, the laws of Deuteronomy (including the shema) focused on the household (בית) of each Israelite family, but at the same time it always has a communal focus as well
(Horsley 2009:17-28).

10.For a more detailed discussion on the structure of the family as described in the Pentateuch see Matthews' (2003:291-299) discussion on family relationships with focus on the texts of the Pentateuch. 
Thus, the responsibility of the parents to educate the child was not one of individual responsibility, but because they formed part of "כלישראל The focus on teaching children 'these words', within the context of the family, always and everywhere, illustrates the pedagogical purpose of Deuteronomy. The contents of the book Deuteronomy were the primary curriculum in the religious education of ancient Israel (Christensen 2001:143).

Jewish children were considered as one of the most important parts of all of Israel. They believed that children were most dear to the heart of God and that their birth is a cause of celebration (Gn 21:6-7). This importance of childbirth is shown clearly in the narrative of God's interaction with Abraham where one of the 'prominent themes that drives the patriarchal narratives is the divine (and sometimes miraculous) provision of seed' (Carroll 2003:620). Because of this importance of children, their education was considered a very important task (Pridmore 1978:3; Rhodes 2003:87). Because they were the Israel of the future, great importance was attached to their education (Pridmore 1978:3). According to Rhodes (2003:87) in the Old Testament, there were no schools for Jewish children to attend and the home was the absolute centre of education for them. In light of what has been said above regarding the cultural differences, such a stance cannot be maintained. For just as the 21st century idea of 'family' is not equivalent to that of ancient Israel, so also the idea of an educational centre (school) would seem strange. There could easily have been certain scribal schools that existed in Israel in the pre-exilic period, but the term 'school' is only mentioned explicitly for the first time in Ben Sira 51:23 $3^{12}$ (c. $180 \mathrm{BCE}$ ), clearly showing the Hellenistic paideia influence on the thoughts of Jewish wisdom (Duling 1995:171; see also Matthews 2006:201-204). During the time referred to in Deuteronomy, the education of the children would not have taken place in an oik $\omega \pi \alpha 1 \delta \varepsilon i \alpha \varsigma$, but rather in the (extended) family group (kinship group). In this case, all the participants of the kinship group would have taken it upon themselves to 'nurture and educate the children. As they grew, these children would be socialized into the appropriate social and gender roles' (Carroll 2003:620). This form of education also included a clear religious component, in teaching the children how they should act in all aspects of life as being part of the covenant people of the Lord God (Carroll 2003:620; Horsley 2009; Pilch 2012:118-121). In the New Testament period, children between the ages of 6 and 12 attended local schools where they would be taught by a rabbi of good character. If a child had to receive further education, they would travel to Jerusalem and study under one of the greater rabbis (Rhodes 2003:87-88). It is however important to realise that the schools were not intended to take the place

11.This does not mean that there were not certain individuals with specific responsibilities in the household. For example the burden of health and reproduction fell most heavily upon the shoulders of individual women within the family' (Nakhai 2014:54). Also the teaching and retelling of the central stories, family' (Nakhai 2014:54). Also the teaching and retelling of the central stories, myths and laws of Israel were passed on by the head of the house (Pilch 2012:118). At the same time it needs to be noted that these roles of the woman and head of because this is what was expected of them by the larger group.

12.'Draw near to me, you who are uneducated, and lodge in a house of instruction

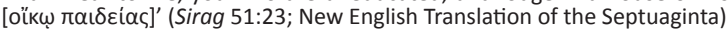

of parents in the religious education of their children. Parents educated their children in the art of godly living, and when the children became adults, they would do the same for their children (Rhodes 2003:88). The Jewish historian Josephus (AD $37-c$. 100) wrote:

Above all we pride ourselves on the education of our children ( $\pi \alpha 1 \delta$ i $\left.\rho \circ \varphi^{\prime} \alpha v\right)$, and regard the most essential task in life the observance of our law, and of the pious practices based thereon. (Ag. Ap. 1.60; Bakke 2005:176)

When taking a closer look at the Hebrew text ${ }^{13}$ of Deuteronomy 6:4-9, the following is important:

The Hebrew word used for 'shall teach' (שננתם), can literally be translated as 'to repeat', 'to whet' or 'to sharpen'. The Hebrew word used for 'children' (בני), refers to a son or daughter of any age. It was therefore, the parent's responsibility to continuously teach their children through repetition (שננתם). Jewish parents wanted to 'whet their children's appetites for the things of God'. (Rhodes 2003:88)

It is also imperative to note that 'teach' is used in the present tense. According to Rhodes (2003:88), this means that this would be a continuous and ongoing activity. Pridmore (1978:3) also states that children were to be taught the words and works of God in the home (בבית), where they were a natural topic of regular conversation. This can also be deducted from the rest of verse 7 , which states that they 'shall talk of them when you sit in your house, and when you walk by the way, and when you lie down, and when you rise'. Religious education was there for not just an activity that should take place on the Sabbath, but something that should happen all day, every day. Although there are few other religious communities that had such a zeal for the education of their children such as Judaism, it was also held in check by the fact that they realised that a child could not be expected to undertake religious obligations beyond their years. One of the finest insights of the rabbinic attitude towards children was that children should be treated as children and not as adults (Pridmore 1978:4).

How does this answer the question, what should be going on, with regard to the role that parents play in the faith development of their young child?

Before answering a note should be given on how a correlation between the family group (kinship-group) in the ancient Mediterranean world and the family of the 21st century could be drawn. As shown above, the family group was a central and important social convention for educating the children of ancient Israel. This central convention taught them all aspects of life, from their roles in the community (e.g. gender roles) to their religious beliefs and practices. The importance of the family institute is further highlighted by the unique attention

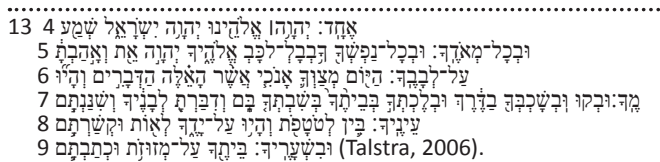


the covenant laws in Deuteronomy (and the rest of the Pentateuch) pay to orphans, that is, children who have lost their family group or an important person therein (the father, e.g. see Horsley's [2009] discussion of this). Although what is meant by family in the 21st century is not the same as in the time of Israel, an important aspect of this article is the centrality role that the family plays in the religious education of children. In light of this, it can be deducted from the text of Deuteronomy that parents (i.e. the family structure whether ancient or modern) play an important role in the faith development and education of young children.

Further, it also emphasises the fact that conversations about religion and faith should be an ongoing and everyday occurrence in the household. Religious education, and conversations about faith, was not a topic that Jewish parents left solely as a responsibility of people outside the kinship group but was conducted specifically 'בבית/בית אב' [in-house or father's house]. That is to say, the core group (kinshipgroup) that gave the children a sense of identity and belonging (Neyrey 1993) was the group that educated them in the myths, customs and beliefs of their group.

Therefore, in our own time, parents should not leave the education of their children to reverends and catechesis teachers, especially considering that today's society is much less group orientated and that the only group children feel they belong to in their early life is the core family.

\section{Guidelines taken from Deuteronomy 6:4-9}

From Deuteronomy 6: 4-9, three guidelines on how parents should teach their children about their faith can be deducted.

Firstly, diligently, as seen in verse 7 . This means that although parents have other important responsibilities, there is none as important as their religious education.

Secondly, it should take place regularly, as seen in the rest of verse 7. Being a part of their child's faith development should not be something that only happens while attending church or catechesis. Talking about faith should be part of everyday life and normal activities around a child's home. According to Van Staden (2015:66), only 11\% of the respondents in the study discussed earlier stated that their parents played no role in their faith development. The following actions played an important role in their relationship between them, their parents and their faith development (Van Staden 2015:66): regularly attending church as a family, discussions about faith and religion between them and their parents and doing Bible study as a family at home.

Thirdly, it should take place through example. In verse 8 and 9, parents are instructed to:

...bind them as a sign on your hand, and they shall be as frontlets between your eyes.9 You shall write them on the doorposts of your house and on your gates. (Dt 6:8-9)
This is a practical step that parents had to take, which continuously reminded them of the Law and how they were supposed to live. Parents could not just instruct their children on how they should live, but had a constant reminder that they too should live and act in an appropriate way. According to Van Staden (2015:66), 95\% of the respondents in the abovementioned study stated that their parent's morals and values had an impact on their own morals and values. From this statistic, it becomes quite clear that the example set by parents play a large role in faith development of children.

\section{How might we respond: Guidelines for parents}

Osmer's fourth task of practical theology (2008:79) is the pragmatic. The task asks, 'How might we respond?' Here, the last question would be aimed at finding practical guidelines to assist parents in the faith development of their children.

From the research done, the following practical guidelines can be deducted:

From birth, the environment in which a child grows up should be one of safety where all basic needs are met. This will ensure for a strong basis of trust on which faith can develop (Fowler 1981:120; Westerhoff 2000:ad loc 89).

The child should see his or her parents interact with faith, through Bible study, church attendance, discussions about faith and their relationships with other people, and be given the opportunity to react to this (Westerhoff 2000:ad loc).

Parents should continuously and regularly educate their children about their religion, as seen in Deuteronomy 6:4-9. This is done through discussion, studying the Word together and setting the right example in their own lives. A subject should also not only be discussed once, but repeatedly, so that the child may grasp the subject and understand.

When children are being told stories from the Bible, parents should try to use vivid images as children at this age are stimulated through the things they can see (Fowler 1981:124). The child's imaginations should be enticed, as this plays an important role in the way that they gather information and develop their knowledge (Fowler 1986b:227). These could include puppets, songs with movements and activities that present the stories in a concrete way, such as building Noah's ark from clay.

As the child is still egocentric (Fowler \& Dell 2006:38), discussions should be aimed at the child's personal needs if possible. This can be done by addressing problems that the child may be facing in their own lives or speaking to an interest that the child has at that time. For example, if a young child is fascinated by animals, it would be a good time to tell them the story of how the world was created, or Noah's ark. A child who is afraid can be taught about a God who is always there, whatever the circumstances. 
From the study published in 2015 (Avenant 2015:65-67), it becomes clear that parents can do the following to assist their children in faith development:

- giving their child(ren) a happy and healthy environment to grow up in

- regularly attending church with their child(ren)

- allowing child(ren) to regularly attend catechesis

- discussing issues of faith, such as baptism with their child(ren)

- telling their own faith story to their child(ren)

- setting good moral values for themselves, which their child(ren) can then follow.

\section{Conclusion}

The importance of the role that parents play in the faith development of children is immense. A baby's or an infant's interaction with his or her parents forms the basis on which he or she will build their developing faith. If this foundation is not placed down correctly, problems might arise later in the child's faith development.

Although it is important for children to attend church with their parents and attend catechesis, the way their parents conduct themselves on a day-to-day basis will also influence the child's faith development. Parents need to discuss matters of faith, relevant to the young child's life and circumstances with the child.

Parents should take the time to have discussions with their children and not go out from the idea that this should be the work of the reverend at church or the catechesis teacher, but work with them to assist their children in their faith development process. Parents should also pay attention to setting a good example for their children and follow simple practical guidelines. Then, they as parents, as well as their significant others, will fulfil the role that they as parents should play in the faith development of their child.

This article sets out to answer Osmer's (2008:4) four questions of practical theology: what is going on, why is this going on, what ought to be going on and how might we respond? As a summary, these questions can now be answered as follows:

What is going on? According to the study published in 2015 by Nel and Van der Westhuizen, parents already play an important role in the faith development of children who later become active young members of the church.

Why is this going on? Faith development theories show that children who form healthy relationships with their caregivers experience their parent's faith in everyday life and can react to what they experience, and children who are taught about religion by engaging their imaginations as well as stimulating them visually are able to develop their faith.

What ought to be going on? Taking Deuteronomy 6:4-9 into account, and looking at it through historical critical lens, one can deduce that the role of parents in the faith development of the child is immense. That is, parents need to pay attention to this responsibility on a regular basis and that this should be done through words and examples.

How might we respond? By taking the theory and statistics into account, it is possible to equip parents to assist their children in the faith development process by giving them practical guidelines to follow.

As Jewish people realised very early on, it is our children who will carry on our faith and religion and share it with others. This will however only be possible if we support them in their process of faith development. For parents to be able to do this, they need to be informed of how they can assist their children in this process and be equipped to do so to the best of their abilities.

\section{Acknowledgements Competing interests}

The authors declare that they have no financial or personal relationships which may have inappropriately influenced them in writing this article.

\section{Authors' contributions}

M.v.N. conceptualised the article, did the research and wrote the manuscript. G.B. functioned as a study leader. Both authors read and approved final version of the article.

\section{References}

Arand, C.P., 2000, That I may be his own: An overview of Luther's catechisms, Concordia Academic Press, St. Louis, MO.

Avenant, J., 2015, 'Geloofsvorming (Faith formation)', in M. Nel \& Z. van der Westhuizen (eds.), Skokkend positief, pp. 63-73, Bybelmedia, Kaapstad.

Bakke, O.M., 2005, When children became people: The birth of childhood in early Christianity, Fortress Press, Minneapolis, MN.

Benson, P.L. \& Eklin, C.H., 1990, Effective Christian education: A national study of protestant congregations, Search Institute, Minneapolis, MN.

Bettelheim, B., 1991, The uses of enchantment: The meaning and importance of fairytales, Penguin Books, New York.

Biddle, M.E., 2003, Deuteronomy, Smyth \& Helwys, Macon, GA.

Boyatzis, C.J. \& Janickie, D.L., 2003, 'Parent-child communication about religion: Survey and diary data on unilateral transmission and bi-directional reciprocity styles', Review of Religious Research 44(3), 252-270. https://doi. org/10.2307/3512386

Browning, D.S., 2007, Equality and the family: A fundamental, practical theology of children, mothers, and fathers in modern societies, William B. Eerdmans Publishing Company, Grand Rapids, MI.

Carroll, M.D., 2003, 'Ophan', in T.D. Alexander \& D.W. Baker (eds.), Dictionary of the Old Testament: Pentateuch, pp. 619-621, InterVarsity Press, Downers Grove, IL.

Christensen, D.L., 2001, World Biblical Commentary: Deuteronomy 1-21:9, Thomas Nelson, Dallas, TX.

Dell, M.L. \& Dulcan, M.K., 1998, 'Childhood and adolescent development', in A. Stoudemire (ed.), Human behaviour: An introduction for medical students, pp. 261-317, Lippincott-Raven, Philadelphia, PA.

Dettoni, J.M., 1994, 'What is spiritual formation', in K.O. Gangel \& J.C. Wilhoit (eds.) The Christian educators handbook on spiritual formation, Baker Books, Grand Rapids, Ml.
Rail

De Vries, M., 2004, Family-based youth ministry, Rev. Edn. InterVarsity Press, IL.

Duling, D.C., 1995, 'The Matthean brotherhood and marginal scribal leadership', in P.F. Esler (ed.), Modeling early Christianity: Social-scientific studies of the New Testament in its context, pp. 154-177, Routledge, London.

Erikson, E.H., 1964, Insight and responsibility, W.W. Norton \& Company, New York. Erikson, E.H., 1968, Identity, youth, and crisis, W.W. Norton \& Company, New York. 
Faust, A. \& Bunimovitz, S., 2014, 'The house and the world: The Israelite house as a microcosm', in R. Albertz, B.A. Nakhai, S.M. Olyan \& R. Schmitt (eds.), Family microcosm, in R. Albertz, B.A. Nakhai, S.M. Olyan \& R. Schmitt (eds.), Family archaeology, epigraphy, and cultural studies, pp. 143-164, Eisenbrauns, archaeology, epigro
Winona Lake, IN.

Firet, J., 1982, Het agogisch moment in het pastoraal optreden, JH Kok, Kampen.

Fowler, J.W., 1981, Stages of faith: The psychology of human development and the quest for meaning, Harper \& Row, San Francisco, CA.

Fowler, J.W., 1986a, 'Faith and the structuring of meaning', in C. Dykstra \& S.D. Parks (eds.), Faith development and Fowler, pp. 15-42, Religious Education Press, Birmingham.

Fowler, J.W., 1986b, 'Stages of Faith' in J.W. Conn (ed.), Women's spirituality: Resources for Christian development, pp. 226-232, Wipf \& Stock Publishers, Eugene, OR.

Fowler, J.W., 1987, Faith development and pastoral care, Fortress Press, Philadelphia, PA.

Fowler, J.W., 1991, Weaving the new creation: Stages of faith and the public church, HarperCollins, New York.

Fowler, J.W., 1996, Faithful change: The personal and public challenges of postmodern life, Abingdon, Nashville, TN.

Fowler, J.W. \& Dell, M.L., 2006, 'Stages of faith from infancy through adolescence: Reflections on three decades of faith development theory', in E.C. Roehlkepartian, P.E. King, L. Wagener \& P.L. Benson (eds.), The handbook of spiritual development in childhood and adolescence, Sage, Thousand Oaks, CA.

Gottman, J.M., 2001, The relationship cure, Three Rivers Press, New York.

Graven, S.N., 1999, 'Thing that matter in the lives of children', in S.K. Morgenthale (ed.), Exploring children's spiritual formation: Foundational issues, Pillars Publishers, River Forest, IL.

Harrison, G.K., 1969, Introduction to the Old Testament, Tyndale Press, London.

Holborn, L. \& Eddy, G., 2011, First steps to healing the South African Family, South African Institute of Race Relations, Richmond, VA.

Horsley, R.A., 2009, Covenant economics: A biblical vision of justice for all, Westminster John Knox Press, Louisville, KY.

Hymans, D.J., 2004, 'The child grew: Understanding children's development', in M.A. Krych (ed.), The ministry of children's education, pp. 35-46, Fortress Press, Minneapolis, MN

Jardine, M.M. \& Viljoen, H.G., 1992, 'Fowler's theory of faith development: An evaluative discussion', Religious Education 87(1), 74-85. https://doi.org/10.1080/ 0034408920870108

Krug, E.F. \& Mikus, K.C., 1999, 'The preschool years' in M.D. Levine, W.B. Carey, \& A.C. Crocker (eds.), Developmental and behavioural paediatrics, pp. 38-50, Saunders, Philadelphia, PA.

Love, P., 2002, 'Comparing spiritual development and cognitive development', Journa of College Student Development 43(3), 357-373.

Lownsdale, S., 1997, 'Faith development across the life span: Fowler's integrative work', Journal of Psychology and Theology 25(1), 49-63. https://doi.org/ 10.1177/009164719702500105

Matthaei, S.H., 2000, Making disciples: Faith formation in the Wesleyan tradition, Abingdon Press, Nashville, TN.

Matthews, V., 2006, Manners and customs in the Bible: An illustrated guide to daily life in Bible times, 3rd edn., Hendrickson Publishers, Peabody, MA.

Matthews, V.H., 2003, 'Family relationships', in T.D. Alexander \& D.W. Baker (eds.), Dictionary of the Old Testament: Pentateuch, pp. 291-299, InterVarsity Press, Downers Grove, IL.

McVann, M., 1993, 'Family-centeredness', in J.J. Pilch \& B.J. Malina (eds.), Handbook of biblical social values, pp. 75-79, Baker Academic, Peabody, MA.
Nakhai, B.A., 2014, 'The household as sacred space', in R. Albertz, B.A. Nakhai, S.M. Olyan \& R. Schmitt (eds.), Family and household religion: Toward a synthesis of Old Testament studies, archaeology, epigraphy, and cultural studies, pp. 53-71, Old Testament studies, archae
Eisenbrauns, Winona Lake, IN.

Nel, M., 2009, 'Inviting and initiating youth into a life of discipleship', Verbum et Ecclesia 30(2), 99-110. https://doi.org/10.4102/ve.v30i2.344

Nel, M. \& Van der Westhuizen, Z., 2015, Skokkend positief, Bybelmedia, Kaapstad.

Newberg, A., 2012, The spiritual brain: Science and religious experiences, Course guide book, The Great Courses, Chantilly, VA.

Neyrey, J.H., 1993, 'Group orientation', in J.J. Pilch \& B.J. Malina (eds.), Handbook of biblical social values, pp. 94-98, Baker Academic, Peabody, MA.

Osmer, R.R., 2008, Practical theology. An introduction, William B. Eerdmans Publishing Company, Grand Rapids, MI.

Parker, S., 2011, 'Spirituality and counseling: A faith development perspective', Journa of Counseling \& Development 89(1), 112-119. https://doi.org/10.1002/j.15566678.2011.tb00067.x

Piaget, J., 1964, The early growth of logic in the child, Routledge, London.

Piaget, J., 1970, Science of education and the psychology of the child, Orion Press, New York.

Pilch, J.J., 2012, A cultural handbook of the Bible, William B. Eerdmans Publishing Company, Grand Rapids, MI.

Pridmore, J., 1978, 'All God's children: Towards a theology of childhood', Third Way 2(16), 3-7.

Prins, R., 1995, 'Die vernuwing van die kategese in die NG Kerk: Die sprong van teorie na praktyk (The renewal of catechesis in the NG church: Moving from theory to practice)' The Dutch Reformed Theological Journal 36(1), 34-52.

Rhodes, R., 2003, Understanding the Bible from A-Z, Harvest House Publishers, Eugene, OR.

Rushdoony, M.R., 2008, Commentaries on the Pentateuch: Deuteronomy, Ross House Books, Valecit, CA.

Smith, C.L. \& Denton, M., 2005, Soul searching: The religious and spiritual lives of American teenagers, Oxford University Press, Oxford.

Stern, D.N., 1985, The interpersonal world of the infant, Basic Books, New York.

Strommen, M.P., 1973, Bridging the gap, Augsburg, Minneapolis, MN.

Thatcher, A., 1999, Marriage after modernity: Christian marriage in postmodern times, Sheffield Academic Press, Sheffield.

Tuckman, B.W. \& Monetti, D.M., 2011, Educational psychology, Cengage Learning, Wadsworth, $\mathrm{OH}$.

Van Staden, M., 2015, 'Geloofsvorming (Faith formation), in M. Nel \& Z. van de Westhuizen (eds.), Skokkend positief, pp.75-77, Bybelmedia, Kaapstad.

Van Staden, T., 2015, 'Gesinne en vriendskap (Healing and friendship)', in M. Nel \& Z. van der Westhuizen (eds.), Skokkend positief, pp. 25-35, Bybelmedia, Kaapstad.

Westerhoff, J., 2000, Will our children have faith?, 3rd rev. Kindle edn., Morehouse Publishing, New York.

Wuthnow, R., 1999, Growing up religious: Christians and Jews and their journeys of faith, Bacon Press, Boston, MA.

Ziettlow, J., 2007, 'The stages of faith development', viewed 20 January 2017, from https://pdfs.semanticscholar.org/f738/75aa0ffc001ebc887fda6e1e19fa ed080438.pd

Zuckerman, B.S., Frank, D.A. \& Augustyn, M., 1999, 'Infancy and toddler years' in M.D. Levine, W.B. Carey \& A.C. Crocker (eds.), Developmental and behavioural paediatrics, pp. 24-36, Saunders, Philadelphia, PA. 